https://helda.helsinki.fi

\title{
Are microfinance markets monopolistic?
}

\section{Kar, Ashim Kumar}

2018

Kar , A K \& Bali Swain , R 2018 , ' Are microfinance markets monopolistic? ' , Applied

Economics, vol. 50 , no. 1 , pp. 1-14 . https://doi.org/10.1080/00036846.2017.1310999

http://hdl.handle.net/10138/298117

https://doi.org/10.1080/00036846.2017.1310999

acceptedVersion

Downloaded from Helda, University of Helsinki institutional repository.

This is an electronic reprint of the original article.

This reprint may differ from the original in pagination and typographic detail.

Please cite the original version. 
APPLIED ECONOMICS, 2018

VOL. 50, NO. 1, 1-14

https://doi.org/10.1080/00036846.2017.1310999

\title{
Are Microfinance Markets Monopolistic?
}

\author{
Ashim Kumar Kar and Ranjula Bali Swain ${ }^{\mathrm{b}}$
}

\begin{abstract}
Do microfinance institutions operate in a monopoly, monopolistic competition environment or are their revenues derived under perfect competition markets? We employ the Panzar-Rosse test on a global panel data to assess the competitive environment in which microfinance institutions (MFIs) of five selected countries operate: Ecuador, India, Indonesia, Peru and Philippines, over the period 2005-2009. We estimate the static and the dynamic revenue tests, with analyses of the interest rate and the return on assets. We control for microfinance specific variables such as capital-assets ratio, loans-assets and the size of the microfinance institution. The analyses also accounts for the endogeneity problem by employing the fixed-effects two-stage least squares (FE-2SLS) and the fixed effects-system generalised method of moments (FE-GMM). Our results suggest that MFIs in Peru and India operate in a monopolistic environment. We also find weak evidence that the microfinance industry in Ecuador, Indonesia and Philippines may operate under perfect competition.
\end{abstract}

JEL classification: D4; G21; L11; N20; O16

Keywords: microfinance, competition, market structure, dynamic panel estimation, Panzar-Rosse revenue tests.

${ }^{a}$ Helsinki Center of Economic Research (HECER), University of Helsinki, Helsinki, Finland; ${ }^{\text {bStockholm }}$ School of Economics \& Department of Economics, Södertörn University, Stockholm, Sweden.

CONTACT Ranjula Bali Swain Ranjula.Bali@hhs.se 


\section{Introduction}

Microfinance, which has been projected as the 'winwin' solution for poverty alleviation, has come under considerable criticism in recent years. Microfinance institutions1 (MFIs) have been accused of charging exorbitant interest rates and employing aggressive loan collection strategies. Are then MFIs operating under monopolistic conditions and charging high interest rates to their predominantly low-income women clients? In this article, we investigate the prevailing MFI market structure in five countries to test if the MFIs operate in a monopolistic competition environment or derive their revenues under perfect competition markets. In a systematic examination of the MFIs in India, Indonesia, Philippines, Peru and Ecuador, we employ the Panzar-Rosse revenue test (PR-RT) to the Microfinance Information Exchange (MIX) market panel data for the period 1996-2010.

The MFIs operate on a double bottom-line principle (Kar 2013)2. Increased competition exacerbates the moral hazard and the information asymmetry problems in the microfinance industry (Berger, Klapper, and Turk-Ariss 2009; Broecker 1990; Marquez 2002; McIntosh and Wydick 2005). Increase in competition has a negative impact on MFIs' outreach, performance and portfolio quality Hartarska and Mersland 2012; Hermes, Lensink, and Meesters 2011; Assefa, Hermes, and Meesters 2013). As competition intensifies, the socially motivated MFIs fail to lend to the poorest and potentially least-profitable borrowers. Any decline in the interest rates charged by the MFIs, therefore results in a drop of the overall profitability and worsens their ability to cross-subsidize (Navajas, Conning, and Gonzalez-Vega 2003; Vogelgesang 2003; McIntosh and Wydick 2005). The for-profit MFIs typically target the wealthier clients and offer larger loans. This attracts the profitable and more productive borrowers of the socially motivated MFIs, thereby worsening their portfolio quality. Increased competition may thus result in 'mission drift'. Rising competition leads to information asymmetries and the lack of information exchange, resulting in the escalation of multiple loans or 'double-dipping' by the borrowers. It also weakens the functioning of the dynamic incentive mechanism3, thus resulting in increased loan default (Hoff and Stiglitz 1998).

\footnotetext{
${ }^{1}$ Operationally, there are non-profit- and social service-oriented MFIs (for example, the Grameen Bank and BRAC in Bangladesh) as well as commercially oriented MFIs (for instance, the Compartamos Banco in Mexico). Socially motivated MFIs put emphasis on providing subsidized credit to help overcome poverty, whereas the financially motivated MFIs emphasize financial sustainability of microfinance operations. ${ }^{2}$ MFIs need to fulfil their social objectives of reaching the very poor (the first bottom line) while attaining financial self-sufficiency (the second bottom line).

${ }^{3}$ Dynamic incentives' link clients' future access to credit with proper repayments of earlier loans to discipline them and ensure repayments on time.
} 
The banking literature investigates the competitive behaviour by applying the conduct parameter method and the PR-RT ${ }^{4}$. However, similar research in microfinance markets is limited to a few studies (Kar and Swain 2014; Baquero, Hamadi, and Heinen 2012; Mersland and Strøm 2012) that examines whether MFIs' attain profitability by charging prohibitive lending rates. The PR-RT model that we employ, depends on the firm-level data, is robust to the geographical definition of the market and allows the use of cross-country data with diversified ownership patterns (Mersland and Strøm 2012). We describe the competitive behaviour of MFIs in the countries using comparative static properties of reduced-form revenue equations. Both static and dynamic panel data (DPD) models are estimated. The dynamic estimation takes care of the dynamic and reforming market landscapes and the regulatory environment of the microfinance industries.

Our results show that the microfinance markets in India and Peru may be both monopolistic and monopolistically competitive and hence susceptible to charging higher interest rates. For Ecuador, Indonesia and Philippines, we cannot reject the hypothesis that they derive their revenues under conditions of perfect competition. These results however should be qualified by mentioning that representative data on microfinance industry does not exist. In particular, the MIX Market data is reported by MFIs on a voluntary basis.

The article is organized as follows. Section 2 provides a brief review of relevant literature basically to explain the theoretical contexts of the PR-RT. A detailed exposition of the methodologies and the empirical specifications of the models are given in Section 3. Section 4 provides data overview and summary statistics. Results are reported in Section 5. Section 6 presents the concluding remarks.

\section{Measuring competition}

In the industrial organization literature, several studies have focused on the level of competition in the banking industry at the country- and region-level aggregations. The literature is broadly divided into studies that adopt a structural (formal) approach and those that follow a nonstructural (informal) approach. The structural method uses the number of banks or the degree of banking industry concentration as a proxy for market power. For example, the n-firm concentration ratios and the Herfindahl-Hirschman index (HHI). This approach follows the

${ }^{4}$ For a detailed literature review on the assessment of competitive behaviour in banking see, for example, TurkAriss (2009). 
structure-conduct-performance (SCP) paradigm. The SCP paradigm suggests that presence of a few large firms is more likely to result in monopolistic behaviour. Thus, the market structure has a direct influence on the firms' economic conduct that affects their market performance. The competing efficiency hypothesis suggests that greater market concentration reflects the efficient firms' market share gains. The positive links, between concentration and profits are caused by both anticompetitive behaviour and higher operating efficiency of larger businesses (Turk-Ariss 2009). Though the structural approach has been frequently employed in the empirical research it is not always supported by standard microeconomic theory (Delis, Staikouras, and Panagiotis 2008). More recently, the non-structural approaches ${ }^{5}$ have been increasingly used to draw inferences on firms' observed behaviour from the estimated parameters of equations derived from theoretical models of price and output determination (Lau 1982; Bresnahan 1982; Panzar andRosse 1987; Berger et al. 2004; Carbo,Maudos, andMolyneux 2009). We employ the PR-RT as ameasure of competition. The PR-RT examines the relationship between price variations and the revenue of the firm to examine if the firmlevel behaviour is in accordance with the textbook models of perfect competition, monopolistic competition or monopoly.

Applying the PR-RT to the microfinance data allows us to assess the competitive conditions in the industry. It is based on the premise that MFIs apply different pricing strategies as input costs change depending on the market structure they operate in. Therefore, whether anMFI operates in a competitive market or exercises some monopoly power may be inferred from the analysis of that MFI's total revenue as it corresponds to changing input prices. It includes all the determinants of costs and demand in the revenue function - particularly factor prices. Given that the MFIs databases (including MIX Market) have limited and mostly involuntary information, making the PR-RT particu larly appropriate for measuring competition/market structure in the microfinance industry.

The profits are maximized where MFIs' (i's) marginal revenue is equal to the marginal cost. At the market level equilibrium under perfect competition, the zero-profit constraint must hold. The H-statistics are then calculated from the comparative statics properties of a reduced form

${ }^{5}$ It is also known as the new empirical industrial organization (NEIO) models. 
revenue equation, which measures the sum of the elasticities of the total revenue R of the MFI with respect to the MFI's $n$ factor input prices $\mathrm{W}_{\mathrm{i}}\left(\right.$ Gischer and Stiele, 2008) ${ }^{6}$ :

$$
\mathrm{H}=\sum_{i=1}^{n} \frac{\partial R}{\partial W_{i}} * \frac{W_{i}}{R}
$$

In this case, the change in factor input prices represents the equilibrium revenues earned by MFI $i$. Based on the above conditions, the PR model provides a measure of the degree of competitiveness, the 'H-statistic', which ranges from minus infinity to unity (de Rozas, 2007). The H-statistic measures the percentage change in an MFI's equilibrium revenue caused by a 1 per cent change in all of the MFI's input prices. Although the information on costs is not required, the computation of the $\mathrm{H}$ statistic requires firm-specific data on revenues and factor prices. This method is a simple, transparent and valuable tool in assessing market conditions. Also, by utilizing MFI-level data, this approach allows for MFI-specific differences in the production function. As revenue data are easy to observe compared to output prices, data availability should not be a constraint. Bikker and Haaf (2000) note that the PR approach basically includes four conditions: (1) firms are operating at their long-run equilibrium, (2) performance of the firm is influenced by the actions of other firms' in the market, (3) the cost structure is homogeneous and, (4) the price elasticity of demand is greater than unity. By not requiring a locational market definition a priori, the PR framework avoids the potential bias caused by the misspecification of the market boundaries; hence, the $\mathrm{H}$-statistic will reflect the average of an MFI's conduct in each market when that MFI operates in more than one market. Another important feature of the PR approach is that it does not require observations on all firms in a market. PR H-statistic is a direct measure of competitiveness that takes into account potential, direct or indirect competitive effects. Thus, applying this method permits us to examine the competitive behaviour of a single firm (Gischer and Stiele, 2008).

Assuming profit maximization, Panzar and Rosse (1987) depicts that in a collusive environment an increase in input prices will increase $\mathrm{MC}$ and reduce equilibrium output and revenues. As Table 1 summarises, $H$ is negative $(H \leq 0)$ either for a monopoly or for an oligopoly (perfectly colluding oligopoly and a homogeneous-conjectural-variations oligopoly). $\mathrm{H}$ equals unity $(\mathrm{H}=1)$ under perfect competition as an increase in input prices will increase $\mathrm{MC}$

${ }^{6}$ The formal derivation of the H-statistic can be found in Panzar and Rosse (1987). 
and MR by the same amount. $\mathrm{H}$ ranges between 0 and $1(0<\mathrm{H}<1)$ under monopolistic competition where an increase in input prices lead to a less than proportional increase in revenues due to inelastic demand faced by the individual MFI. Panzar and Rosse (1987) further note that, from an econometric standpoint, the rejection of $\mathrm{H} \leq 0$ rules out the monopoly model; the rejection of $\mathrm{H} \leq 1$ excludes all the three models; and the rejection of both $\mathrm{H} \leq 0$ and the $\mathrm{H}$ $=1$ hypothesis (but not the $\mathrm{H} \leq 1$ hypothesis) implies that only monopolistic competition model is consistent with the data. Refer to Bikker et al. (2009), for a detailed discussion on the interpretations of the H-statistic.

[Insert Table 1 about here]

\section{Model Specification and Estimation}

\section{The short-run H-statistic}

The country-level H-statistics are estimated by the standard reduced-form specification on the panel data for each country as follows:

$$
\begin{gathered}
\ln T R_{\mathrm{it}}=\alpha+\beta_{1} \ln \left(\mathrm{W}_{\mathrm{L}, \mathrm{it}}\right)+\beta_{2} \ln \left(\mathrm{W}_{\mathrm{F}, \mathrm{it}}\right)+\beta_{3} \ln \left(\mathrm{W}_{\mathrm{K}, \mathrm{it}}\right)+\gamma_{1} \ln \left(\mathrm{Y}_{1, \mathrm{it}}\right)+\gamma_{2} \ln \left(\mathrm{Y}_{2, \mathrm{it}}\right)+\gamma_{3} \ln \left(\mathrm{Y}_{3, \mathrm{it}}\right)+\mathrm{u}_{\mathrm{i}} \\
+\varepsilon_{\mathrm{it}}
\end{gathered}
$$

where the subscripts $i$ and $t$ refer to MFI $i$ operating at time $t$. The dependent variable $\mathrm{TR}_{\mathrm{it}}$ indicates total revenue defined as the financial revenues net of financial and operating expenses, impairment losses and taxes. Financial revenue of an MFI includes all interest, fees and commissions incurred on the loan portfolio and other financial assets. Financial revenue may have a subsidised component from different sources for some MFIs. Since we do not have access to data on subsidies, it has not been included in our analysis leading to a possible bias in the results. This amount also includes other revenues related to the provision of financial services $^{7}$. Bikker et al. (2009) note that the Panzar-Rosse price function, or the scaled revenue equation cannot be used to infer the degree of competition and that only an unscaled revenue equation yields a valid measure for competitive behaviour. Following Bikker et al. (2009) we employ an unscaled measure of total revenue (interest income). The set of explanatory variables include the three factor input prices. Most microfinance databases including the MIX, lack the appropriate data. We therefore follow Turk-Ariss (2009) and Delis et al. (2008) to

\footnotetext{
${ }^{7}$ For further details, see: http://www.mixmarket.org/fr/about/faqs/glossary\#ixzz2anfY8d74
} 
construct alternative proxies. Price of labour, $\mathrm{W}_{\mathrm{L}, \mathrm{it}}$, is proxied by the ratio of personnel expenses to total assets (pea); price of funds, $\mathrm{W}_{\mathrm{F}, \mathrm{it}}$, is measured as the ratio of interest expenses to total assets $(f e a)$; and price of physical capital, $\mathrm{W}_{\mathrm{K}, \mathrm{it}}$, is defined as the ratio of the administrative expenses to total assets (aea). The interest expenses includes interest, fees and commissions incurred on all liabilities, including the deposit accounts of the clients held by the MFI, borrowings, subordinated debt and other liabilities. $Y_{1, \text { it }}$ and $\mathrm{Y}_{2, \text { it }}$ represent capitalisation and risk scenarios of MFIs proxied by the equity-to-assets (or capital-assets-ratio) ratio (car) and the loans-to-assets ratio (glpta) respectively. The equity-to-assets ratio (car) reflects the differences in the capital structure. Loans-to-assets ratio (glpta) represents the loan risk of the sampled MFIs and is used as a control variable for their business and portfolio mix. It is expected that better capitalization levels and a higher allocation of assets to loans will generate more revenues and therefore are positively associated to the dependent variable. To control for potential effects of MFI's size, we include $Y_{3, \text { it }}$ which is the natural logarithm of the total assets. While there is no expectation about the sign on total assets, the estimation results would provide information on whether the MFIs face economies or diseconomies of scale. The variable definitions are provided in Table 2.

Panzar and Rosse (1989) note that based on the reduced-form revenue equation (2) the Hstatistics can be written as:

$$
\mathrm{H}=\beta_{1}+\beta_{2}+\beta_{3}
$$

where $\mathrm{H}$ is the sum of the elasticities of the reduced form revenue with respect to all the factor prices.

[Insert Table 2 about here]

\section{The long-term E-statistic}

A critical feature of the $\mathrm{H}$-statistic is that the test must be undertaken on observations that are in long-run equilibrium at each point in time. Since the competitive capital markets will equalize the risk-adjusted rate of return across MFIs, the rate of return should not be correlated statistically with the input prices in equilibrium. Thus, like Shaffer (1982), instead of the Hstatistic we compute the long-run E-statistic to test for the equilibrium. The long-run equilibrium perspective is estimated using the following panel data specification: 
$\ln \left(1+\mathrm{ROA}_{\mathrm{it}}\right)=\alpha+\beta_{1} \ln \left(\mathrm{W}_{\mathrm{L}, \mathrm{it}}\right)+\beta_{2} \ln \left(\mathrm{W}_{\mathrm{F}, \mathrm{it}}\right)+\beta_{3} \ln \left(\mathrm{W}_{\mathrm{K}, \mathrm{it}}\right)+\gamma_{1} \ln \left(\mathrm{Y}_{1, \mathrm{it}}\right)+\gamma_{2} \ln \left(\mathrm{Y}_{2, \mathrm{it}}\right)+\gamma_{3}$

$\ln \left(\mathrm{Y}_{3, \mathrm{it}}\right)+\mathrm{u}_{\mathrm{i}}+\varepsilon_{\mathrm{it}}$

where the return on assets less taxes (ROA) is used as the dependent variable instead of the interest income. ROA is widely used as a financial performance indicator in the microfinance literature. In equilibrium $(\mathrm{E}=0)$, the market forces equalise ROA across the firms, thus the level of ROA is not linked to the input prices. To avoid the loss of observations, a constant (one) is added to ROA to exclude the possibility of taking a natural logarithm of a negative number. The equilibrium E-statistic is calculated as the sum of the input price elasticities. The hypothesis $\mathrm{E}=0$ is tested and if rejected, the market is not in equilibrium, intuitively indicating that in the long-run ROA is not related to input prices.

Endogeneity is another problem in the estimation as the unobservables like managerial competence or aptitude simultaneously determine the total revenue and capital-assets-ratio. ${ }^{8}$ It also arises due to uncontrolled confounding variable as both capital-assets-ratio and ROA are determined by total assets which consists of interest income and fees component. The MFIindividual effect may also suffer from unobserved firm heterogeneity (such as, managerial capabilities) due to the diversified characteristics of the sampled MFIs. To deal with the endogeneity problem, we estimate the fixed-effects two-stage least squares (FE2SLS) for the short-term and the long-term static revenue test.

Estimations of one-way static fixed effects models of this type may result in grossly misleading inferences. We thus require a robustness check of our static results against the dynamic model results for at least three reasons. First, the competitive paradigm makes clear dynamic predictions as firms fight for profits: strong players pass the market test and continue, while weak performers exit or shrink (Goddard and Wilson, 2009). Second, if the total revenues in the current year are linked with those of the previous year(s), then the model misspecifications potentially result in a pattern of autocorrelation in the error terms. With auto-correlated disturbances in with few time identifiers and large number of firms, the fixed and random effects estimators are biased toward zero. This potentially creates misleading inferences on the nature or intensity of competition. Third, as Delis et al. (2008) notes, accommodation of new

\footnotetext{
${ }^{8}$ For a detailed discussion on the endogeneity between the capital-assets-ratio and total revenue see Delis et al. (2008).
} 
input prices is not instantaneous, but partial, and therefore, a dynamic estimation of the relationship can give better estimates of the market power.

\section{Dynamic Modelling}

Dynamic panel data (DPD) modelling takes care of the changes that occur over time in sampled countries' market landscapes and regulatory environments. It also potentially solves the inference limitations associated with data non-stationarity (which is a common problem of the time series dimension of panel data). The dynamic extension of the static model (equation 2) is specified with autoregressive-distributed lag model as follows (Delis et al., 2008):

$$
\begin{aligned}
& \ln \mathrm{TR}_{\mathrm{it}}=\alpha^{\prime}+\beta_{10} \ln \mathrm{TR} \mathrm{R}_{\mathrm{i},(\mathrm{t}-1)}+\beta_{1}^{\prime} \ln \left(\mathrm{W}_{\mathrm{L}, \mathrm{it}}^{\prime}\right)+\beta_{11}^{\prime} \ln \left(\mathrm{W}_{\mathrm{L}, \mathrm{i}(\mathrm{t}-1))}^{\prime}+\beta_{2}^{\prime} \ln \left(\mathrm{W}_{\mathrm{F}, \mathrm{it}}^{\prime}\right)+\beta_{21}^{\prime} \ln \left(\mathrm{W}_{\mathrm{F}, \mathrm{i}(\mathrm{t}-1)}^{\prime}\right)\right.
\end{aligned}
$$

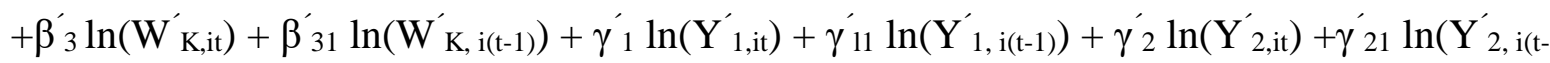

$$
\begin{aligned}
& \text { 1)) }+\gamma_{3}^{\prime} \ln \left(\mathrm{Y}_{3, \mathrm{it}}^{\prime}\right)+ \\
& \gamma_{31}^{\prime} \ln \left(\mathrm{Y}_{3, \mathrm{i}(\mathrm{t}-1)}^{\prime}\right)+\mathrm{u}_{\mathrm{i}}+\varepsilon_{\mathrm{it}}
\end{aligned}
$$

where $(\mathrm{t}-1)$ is the one-period time lag, $\mathrm{u}_{\mathrm{i}}$ are the individual effects and $\varepsilon_{\mathrm{it}}$ is the idiosyncratic disturbance. For the set of explanatory variables, $x$, we assume that $E\left(\varepsilon_{i t} \mid x_{i t}, u_{i}\right)=0$, which implies that there is no possibility of feedback from lagged revenue to current $\mathrm{x}$ values. Thus, as in the static case, the $\mathrm{H}$-statistic is obtained by $\mathrm{H}^{\prime}=\beta^{\prime}{ }_{1}+\beta^{\prime}{ }_{2}+\beta_{3}^{\prime}$.

As explained in the previous section, the long-run equilibrium is tested using the following specification:

$$
\begin{aligned}
& \ln \left(1+\mathrm{ROA}_{\mathrm{it}}\right)=\alpha^{\prime}+\beta_{10} \ln \mathrm{TR}_{\mathrm{i},(\mathrm{t}-1)}+\beta_{1}^{\prime} \ln \left(\mathrm{W}_{\mathrm{L}, \mathrm{it}}^{\prime}\right)+\beta_{11}^{\prime} \ln \left(\mathrm{W}_{\mathrm{L}, \mathrm{i}(\mathrm{t}-1)}^{\prime}\right)+\beta_{2}^{\prime} \ln \left(\mathrm{W}_{\mathrm{F}, \mathrm{it}}^{\prime}\right)+\beta_{21}^{\prime} \\
& \ln \left(\mathrm{W}_{\mathrm{F}, \mathrm{i}(\mathrm{t}-1)}^{\prime}\right) \\
& +\beta_{3}^{\prime} \ln \left(\mathrm{W}_{\mathrm{K}, \mathrm{it}}^{\prime}\right)+\beta_{31}^{\prime} \ln \left(\mathrm{W}_{\mathrm{K}, \mathrm{i}(\mathrm{t}-1)}^{\prime}\right)+\gamma_{1}^{\prime} \ln \left(\mathrm{Y}_{1, \mathrm{it}}^{\prime}\right)+\gamma_{11}^{\prime} \ln \left(\mathrm{Y}_{1, \mathrm{i}(\mathrm{t}-1)}^{\prime}\right)+\gamma_{2}^{\prime} \ln \left(\mathrm{Y}_{2, \mathrm{it}}^{\prime}\right) \\
& +\gamma_{21}^{\prime} \ln \left(\mathrm{Y}_{2, \mathrm{i}(\mathrm{t}-1))}^{\prime}+\gamma_{3}^{\prime} \ln \left(\mathrm{Y}_{3, \mathrm{it}}^{\prime}\right)+\gamma_{31}^{\prime} \ln \left(\mathrm{Y}_{3, \mathrm{i}(\mathrm{t}-1)}^{\prime}\right)+\mathrm{u}_{\mathrm{i}}+\varepsilon_{\mathrm{it}}\right.
\end{aligned}
$$

where ROA is the return on assets less taxes and the other variables are the same as defined previously.

The "system GMM" estimator is employed to estimate the model, which is the augmented version of Arellano-Bond (1991). The "system GMM" estimator sets up the model as a system of equations, one for each time period, where the instruments - created from the lagged values - applicable to each equation differ. Thus, equations (5) and (6) have been estimated 
using the two-step system GMM method proposed by Blundell and Bond (1998) ${ }^{9}$ with Windmeijer's (2005) finite-sample correction for the two-step covariance matrix. Following Delis et al. (2008), variable capital-assets-ratio is used as an endogenous variable. Then, as suggested by Bond (2002), the endogenous variable (i.e., capital-assets-ratio) is instrumented following 'GMM style' symmetrically to the dependent variable (unscaled total revenue) with an autoregressive error term similar to the static case.

\section{Data}

MFI-level financial, portfolio and outreach performance data were retrieved in 2013 from the MIX Market database ${ }^{10}$. Financial data and social performance indicators of over 2,000 MFIs functioning worldwide were available at that time. However, data from all of them could not be used as we had to introduce some filtering rules before editing and utilizing. The selection criteria for MFIs were mostly based on the available amount and quality of the data. The MIX Market uses 'diamonds' to rank MFI data where a rank of the highest of 5-diamonds means the best quality ${ }^{11}$. This study sampled MFIs which have at least a 3-diamonds ranking: 5-diamonds (27.59\%), 4-diamonds (30.46\%) and 3-diamonds (40.62\%). Also, data on all relevant variables were not available. Besides, MFIs that did not have data on the main variables were deleted. Also, MFIs with less than at least three yearly observations were omitted from the sample. Application of these eligibility criteria reduced the sample size significantly. The study finally employs static and dynamic models to test the degree of competitiveness in the vibrant microfinance industries of India, Indonesia, Philippines, Peru and Ecuador covering a period of 15 years - 1996-2010. These countries have distinctive characteristics in the liberalization and regulation of MFIs functioning within the country ${ }^{12}$. Five separate panel data sets have been created corresponding to the microfinance sectors in each of these countries. The data are unbalanced as all MFIs included in the database do not have equal number of observations for every year.

\footnotetext{
9The original Arellano-Bond "difference GMM" model transforms the regressors by differencing and uses the generalized method of moments (Hansen, 1982). A potential weakness of this estimator was revealed in later works by Arellano and Bover (1995) and Blundell and Bond (1998). The lagged levels are often rather poor instruments for first differenced variables, especially if the variables are close to a random walk. Their modification of the estimator includes lagged levels as well as lagged differences.

${ }^{10}$ Individual MFI data are maintained in their publicly available information platform: www.mixmarket.org.

${ }^{11}$ The level of disclosure for each MFI is indicated through a 'diamond' system: The higher the number of diamonds, the higher the level of disclosure.

${ }^{12}$ Another country with significant history and vibrant presence of microfinance activities, Bangladesh, is excluded from the sample mainly due to nonavailability of sufficient number of observations on selected MFIs that can handle statistical tests and dynamic panel data estimations as applied in this exercise.
} 
These countries were selected for a number of reasons. First, the study attempts to cover regional differences in the level of competition. So, the sampled countries come from three different developing regions: South Asia, East Asia and the Pacific and Latin America and the Caribbean. Also these countries have differences in their regulatory frameworks. Truly, the revenue streams of MFIs may vary from country to country depending on their product portfolio mix. For example, Indonesian MFIs largely generate revenues from micro-savings. Whereas, in India, MFIs mostly rely on microloans for their revenue generation. So, seemingly these two microfinance industries have different types of revenue streams and are difficult to compare. But as we are employing the PR-RT, differences in country-specific revenue sources do not matter much. Thus, we can compare the revenue stream of a 'micro-saving'-centric country (Indonesia) with that of a 'microloan'-centric country (India) (Kar 2016).

Second, countries where the microfinance sectors are getting increasingly competitive and characterized by differing levels of concentration have been chosen. For instance, the HHI for India ranges from a high of 111 in 2004 to a low of 89 in $2010^{13}$. Contrariwise, the Indonesian microfinance sector is much concentrated, with an HHI of 301 in 2010, up from 90 in 2004, exhibiting much higher concentration level than the average of EAP region countries (41 in 2004 and 56 in 2010). The concentration level of the microfinance industry in Philippines is also increased in 2010 (an HHI of 41 in 2004 to 56 in 2010). Concentration levels of the microfinance sectors in Peru and Ecuador, however, have decreased in 2010. Thus, by including these five countries in the databases, the study covers microfinance markets of both high (Indonesia and Philippines) and low (India, Peru and Ecuador) concentrations.

Third, these countries are of varying magnitudes of population, GDP and footprint of the microfinance sectors. India is one of the biggest countries in the world, with a population of around 1.27 billion in 2013, as well as a country boasting several big MFIs in the world. On the contrary, for instance, Ecuador and Peru are much smaller than India having only 15.4 million and 30.4 million in population respectively. Philippines (97.7 million) and Indonesia (250 million) are two other sampled countries which have quite a high population in comparison with Ecuador and Peru. These countries also vary in terms of their magnitudes of GDP per capita. For example, per capita GDP in Peru was 6,796 U.S. dollars in 2012, the

\footnotetext{
${ }^{13}$ The HHI and the GDP figures are not presented in the summary statistics, but they are available from the authors on request.
} 
highest, whereas in that year India's per capita GDP was the lowest among these countries, only 1,489 U.S. dollars. Per capita GDP of Indonesia, Philippines and Ecuador, however, were 3,557 USD, 2,587 USD and 5,425 USD, respectively. The MIX Market database has a very comprehensive coverage of functioning MFIs in most countries. In 2013, the MIX Market database had the data for 149 Indian MFIs. Other countries have very high numbers of MFIs in operation too: Indonesia (59), Philippines (93), Peru (72) and Ecuador (50). Thus, these countries are very important regarding the footprints of respective microfinance sectors.

\section{[Insert Table 3 about here]}

The static models estimated in the analysis utilized data for the whole sample period - 19962010. However, the dynamic models have been estimated for the period 2005-2009. The reason for doing so is the problem of too many instruments as a large collection of instruments can overfit endogenous variables and the instrument count is quadratic in the time dimension of the panel, T (Roodman 2009). After applying the filtering rules, the final sample covers a total of 342 MFIs: India (106 MFIs), Indonesia (45 MFIs), Philippines (79 MFIs), Peru (62 MFIs) and Ecuador (50 MFIs). The sampled MFIs capture a good deal of diversity in itself and are indeed a good representation of microfinance service providers worldwide which disclose relevant information on their internal operation. Expectantly, diversity among the five selected countries, at least in terms of their geographical locations and dynamics of transitions, is relevant as a framework for studying competitiveness of the microfinance industry. We also wanted to keep new, young and matured MFIs. Again, four types of MFIs are basically sampled: NGO, non-bank financial institution, bank and credit union (summary statistics are provided in Table 3) .

\section{Discussion of results}

We now report the static and the dynamic revenue test results fromour analyses ofH for the total revenue, the interest income and the overall profitability, ROA. Our GMMFE results enable us to obtain a complete picture of the competitive situation for the averageMFIs in the selected countries. The estimation first proceeds under the assumption of instantaneous adjustment in static FE, followed by the test for the long-run equilibrium. Second, the dynamic panel model is estimated to account for the changes in the markets and the regulatory environment in the sampled countries. 
[Insert Table 4 about here]

\section{Static revenue tests}

As a standard procedure for estimating the H-statistics, we apply the FE (the random effects are estimated but not reported in the article) regression with the 2SLS technique on the static version of our estimation model, commonly known as Panzar-Rosse static revenue tests. The results are presented in Table 4. The coefficients on the proxies for the input prices are negative and statistically significant for theMFIs in Indonesia and Peru. Positive significant input price coefficients generally suggest sufficient stability of the equations. Negative significant coefficients of the input prices in Indonesia and Peru, however, indicate excess capacity in these microfinance industries. Positive significant coefficients of the loans-to-assets variable and the MFI size (in logs) confirm the positive effects of loan and scale (economies of scale) on the interest income. The positive capitalization (equity-to-assets) variable (though statistically insignificant) for the MFIs in Peru indicates that improved capitalization may raise revenues. This is also in line with the theoretical predictions.

The PR H-statistics is negative for most countries but statistically significant only for the MFIs in Peru. Wald tests for the hypotheses of $\mathrm{H}=0$ (monopoly) and $\mathrm{H}=1$ (perfect competition) are both rejected at 5\% level for Peru. This leads us to reject the monopoly hypothesis, the conjectural variations short-run oligopoly hypothesis and the hypothesis of perfect competition, in favour of the hypothesis that in Peru, MFIs' revenues behave as if they are earned under monopolistic competition. Therefore, the dominant market form in Peru is monopolistic competition. A closer examination of the results from Indonesia and Ecuador reveals that we can reject the presence of perfect competition environment in their MFI industry. However, these results cannot be taken at face value. As Bikker, Shaffer and Spierdijk (2009) explain, a negative H-statistic may also arise under the conditions of long-run competition with constant average cost and short-run competition. Thus, one may have to examine other scenarios including individual cost structures, for instance. We test and report the long-run equilibrium results in Table 5. The Wald tests fail to reject the hypothesis of equilibrium $(\mathrm{E}=0)$. The value of the E-statistics is very close to zero, which indicates that the long-run equilibrium conditions are met. Our results also suggest that the static models underestimate the market power in India and Philippines. 


\section{Dynamic revenue tests}

The dynamic revenue tests that account for the market and regulatory changes are estimated for the H-statistics in Table 6. The negative coefficients of the input prices increased factor costs lead to lower revenue. This could also indicate cost-cutting efforts by MFIs. However, the coefficients on input prices are statistically insignificant, except the price of labour (WL) in India and price of loanable funds (WF) in Indonesia. Major contributors to the H-statistics vary from country to country. For instance, in India, Peru and Ecuador, price of labour (WL) contributes more to the increase in competition (H-statistic), while in Indonesia and Philippines price of loanable funds (WF) and price of capital (WK) are the major contributors, respectively. Contributions of some of the input price coefficients are sometimes negligible. For example, overall impact of price of capital (WK) in India on the factor price elasticity is negligible. This result is in line with previous banking studies (see, for instance, Turk-Ariss 2009; De Rozas 2007). As expected, the coefficients of the equity-to-assets ratio are all positive and generally highly significant in India and Philippines. Positive significant coefficients on the equitytoassets variable indicate that the protected capital buffers encourage risk-taking and that the well-capitalized MFIs are not involved in riskier operations.

[Insert Table 5 about here]

[Insert Table 6 about here]

Another reason might be the absence of regulatory pressures so that riskier MFIs are allowed to carry more equity. Hence, higher capital ratio will generate larger revenues and MFIs are likely to improve their earning capability through riskier loan portfolios. Reported positive significant coefficient for the loans-to-assets variable seems plausible as more loans potentially reflect higher income. The positive significant MFI size indicates that the sample MFIs experience economies of scale. These results validate the static revenue test results.

A closer look at the results of the dynamic revenue tests $\mathrm{H}$-statistics reveals a negative value for most countries. For India and Peru, these are statistically significant values. The tests of hypotheses of $\mathrm{H}=0$ (monopoly) and $\mathrm{H}=1$ (perfect competition) are both rejected at $5 \%$ level for the MFIs in India and Peru. These results resonate with the static revenue results for Peru as a country with a MFI industry that has monopolistic competition. The results also indicate that the total revenues of the MFIs in India are earned under conditions of monopolistic 
competition and any form of conjectural variation oligopoly and monopoly can be ruled out during the sample period. For Indonesia, Philippines and Ecuador, we reject a perfect competition environment in their MFI industry. The negative $\mathrm{H}$-statistic in these countries, may be a result of many situations and requires a careful examination of other scenarios including individual cost structures etc., as mentioned earlier (Bikker, Shaffer, and Spierdijk 2009). In order to validate the above test results, the long-run equilibrium condition has to be met. These results are presented in Table 7. The tests for long-run equilibrium produce E-statistics which are close to zero and are further supported by the Wald tests confirming that the long-term equilibrium criterion has been met.

The overall predictions regarding the market structures of the MFI industry in Peru and India give a clear indication of monopolistic competition. The evidence for the MFIs in Peru reflects that the total revenue is earned under conditions of monopolistic environment. The dynamic model results confirm that the dominant market form in India's MFI industry is monopolistic competition. For Indonesia, Philippines and Ecuador, the results indicate that we can statistically reject perfect competition. The presented estimations also indicate that both the static and the dynamic revenue tests give consistent results, which further confirm the validity of the methodology we apply and acts as an additional tool for robustness check. The static and dynamic revenue tests were also estimated for the non-profit, forprofit and the regulated type of MFIs in the sample countries ${ }^{14}$. The results are consistent across all the categories of the MFIs and confirm the robustness of the reported results.

[Insert Table 7 about here]

\section{Conclusions}

Competition in the microfinance industry is important to the broader development agenda. Increased competition is expected to result in greater benefits in terms of better access to credit with lower interest rates. This may not always be the case in the microfinance industry and in fact, previous studies have suggested that competitive microfinance markets might cause the markets to fail. One plausible reason is that without information sharing, borrowers may lack the discipline to repay in a competitive set-up. However, only a few studies have attempted to determine the extent of competition in the microfinance industries. We investigate this by

\footnotetext{
${ }^{14}$ The results are available on request from the authors.
} 
applying the PR-RT to get the H-statistics to account for the intensity of competition in five vibrant microfinance industries: India, Indonesia, Philippines, Ecuador and Peru. The analysis extends beyond the static revenue test to include the dynamic version of the reduced-form models used in estimations, to substantiate whether predictions regarding the market structure remain unchanged. The resulting specifications have been tested for panel data from the microfinance industries of the above-mentioned countries spanning the period 1996-2010.

Static and dynamic models estimated for the MFIs in India and particularly Peru deliver consistent results. The MFI industry in these two countries can be described as monopolistically competitive. This clearly suggests that the concentration levels are differing (from high to low) in the sampled microfinance markets. However, there is scope to make these markets more competitive by creating more conducive atmosphere for the participation of other MFIs and reducing unnecessary restrictions on their activities. Caution needs to be maintained as promoting competition may not improve the incumbent socially motivated MFI's financial sustainability and outreach performance, and may in fact result in mission drift concerns.

A competitive microfinance industry may not guarantee better performance of an MFI, whereas monopoly of an altruistic MFI can be good for their clients. Owing to competitive pressures, MFIs cannot always pass on increase in input prices to their clients. To achieve financial sustainability and balancing it with higher outreach are ongoing challenges for MFIs and it is necessary for them to improve their efficiency by reducing costs.

A monopolistic competition structure allows for product differentiation. Microfinance sectors in the sampled countries are traditionally highly concentrated markets. MFIs tend to differ with respect to product quality and advertising, although their core business is fairly homogeneous. Countries with monopolistically competitive market structures are not generally characterized either as a monopoly or conjectural variations short-term oligopoly. The empirical findings reveal that market power resulting from high concentration levels does not exclude competitive behaviour. This suggests that other factors may account for differences in the degree of competition in the microfinance industries under scrutiny.

These results have significant implications for researchers and policymakers. Although some of the markets seem relatively oligopolistic or monopolistic (in Peru and India), our results confirm that there are weak signs of monopoly in Indonesia and Philippines and monopolistic 
competition in Ecuador. Further research can contribute to the existing knowledge in a number of ways. One major constraint is the lack of data. Researchers can focus on the disaggregated sample of MFIs, based on different loan methods, legal types and regulatory regimes. Further investigation is to examine the impact of the depth of outreach on the revenues and lending rates of MFIs. This would be particularly crucial in understanding if greater competition in microfinance industry leads to mission drift.

\section{Acknowledgements}

The first author Kar gratefully acknowledges research funding from the Academy of Finland (grant number 260894) and Bali Swain gratefully acknowledge research grant from the Swedish Research Council VR/Uforsk.

\section{Disclosure statement}

No potential conflict of interest was reported by the authors.

\section{Funding}

The first author Kar gratefully acknowledges research funding from the Academy of Finland (grant number 260894) and Bali Swain gratefully acknowledge research grant from the Swedish Research Council VR/Uforsk.

\section{References}

Arellano, M., and S. Bond. 1991. "Some Tests of Specification for Panel Data: Monte Carlo Evidence and an Application to Employment Equations." The Review of Economic Studies 58 (2): 277-297. doi:10.2307/2297968.

Arellano, M., and O. Bover. 1995. "Another Look at the Instrumental Variable Estimation of Error-Components Models.” Journal of Econometrics 68 (1): 29-51. doi:10.1016/0304-4076(94)01642-D.

Assefa, E., N. Hermes, and A. Meesters. 2013. "Competition and the Performance of Microfinance Institutions.” Applied Financial Economics 23 (9): 767-782. doi:10.1080/ 09603107.2012.754541.

Baquero, G., M. Hamadi, and A. Heinen. 2012. "Competition, Loan Rates and Information Dispersion in Microcredit Markets." European School of Management and Technology Working Paper No. 12-02, Berlin. 
Berger, A. N., A. Demirgüç-Kunt, R. Levine, and J. G. Haubrich. 2004. "Bank Concentration and Competition: An Evolution in the Making." Journal of Money, Credit and Banking 36 (3) Part 2): 433-451. doi:10.1353/mcb.2004.0040.

Berger, A. N., L. F. Klapper, and R. Turk-Ariss. 2009. "Bank Competition and Financial Stability.” Journal of Financial Services Research 35 (2): 99-118. doi:10.1007/s10693-0080050-7.

Bikker, J. A., and K. Haaf. 2000. "Measures of Competition and Concentration: A Review of the Literature.” Research Series Supervision 30, De Nederlandsche Bank Amsterdam.

Bikker, J. A., S. Shaffer, and L. Spierdijk. 2009. "Assessing Competition with the PanzarRosse Model: The Role of Scale, Costs, and Equilibrium.” DNB Working Papers 225, Netherlands Central Bank, Research Department.

Blundell, R., and S. Bond. 1998. "Initial Conditions and Moment Restrictions in Dynamic Panel Data Models.” Journal of Econometrics 87 (1): 115-143. doi:10.1016/S03044076(98)00009-8.

Bond, S. 2002. "Dynamic Panel Data Models: A Guide to Micro Data Methods and Practice." Portuguese Economic Journal 1 (2): 141-162. doi:10.1007/s10258-002-0009-9.

Bresnahan, T. F. 1982. "The Oligopoly Solution Concept Is Identified.” Economic Letters 10 (1-2): 87-92. doi:10.1016/0165-1765(82)90121-5.

Broecker, T. 1990. "Credit-Worthiness Tests and Interbank Competition." Econometrica 58 (2): 429-452. doi:10.2307/2938210.

Carbo, S. D., H. J. Maudos, and P. Molyneux. 2009. "Cross-Country Comparisons of Competition and Pricing Power in European Banking." Journal of International Money and Finance 28 (1): 115-134. doi:10.1016/j.jimonfin.2008.06.005.

De Rozas, G. L. 2007. “Testing for Competition in the Spanish Banking Industry: The Panzar-Rosse Approach Revisited.” Banco de Espaňa Working paper No. 0726.

Delis, M. D., K. C. Staikouras, and T. V. Panagiotis. 2008. "On the Measurement of Market Power in the Banking Industry." Journal of Business, Finance and Accounting 35 (7-8): 1023-1047. doi:10.1111/j.1468-5957.2008.02098.

Gischer, H., and M. Stiele. 2008. "Competition Tests with a Non-Structural Model: The Panzar-Rosse Method Applied to Germany's Savings Banks." German Economic Review 10 (1): 50-70. doi:10.1111/j.1468-0475.2008.00441. 
Goddard, J., and J. O. S. Wilson. 2009. "Measuring Competition in Banking: A Disequilibrium Approach.” Journal of Banking and Finance 33: 2282-2292. doi:10.1016/j.jbankfin.2009.06.003.

Hansen, L. P. 1982. "Large Sample Properties of Generalized Method of Moments Estimators.” Econometrica 50 (4): 1029-1054. doi:10.2307/1912775.

Hartarska, V., and R. Mersland. 2012. "Which Governance Mechanisms Promote Efficiency in Reaching Poor Clients? Evidence from Rated Microfinance Institutions." European Financial Management 18 (2): 218-239. doi:10.1111/j.1468-036X.2009.00524.

Hermes, N., R. Lensink, and A. Meesters. 2011. "Outreach and Efficiency of Microfinance Institutions.” World Development 39 (6): 938-948. doi:10.1016/j.worlddev.2009.10.018.

Hoff, K., and J. E. Stiglitz. 1998. "Moneylenders and Bankers: Price-Increasing Subsidies in a Monopolistically Competitive Market." Journal of Development Economics 55 (2): 485 518. doi:10.1016/S0304-3878(96)00443-9.

Kar, A. K. 2013. "Double Bottom Lines in Microfinance: Are They Mutually Exclusive?." Journal of Small Business \& Entrepreneurship 26 (1): 87-107. doi:10.1080/08276331.2012.761804.

Kar, A. K., and R. B. Swain. 2014. "Competition in Microfinance: Does It Affect Performance, Portfolio Quality and Capitalization?" In Microfinance Institutions: Financial and Social Performance, Edited by R. Mersland and Ø. Strøm, 208-226. Hampshire: Palgrave Macmillan.

Kar, A. K. 2016. "Measuring competition in microfinance markets: a new approach." International Review of Applied Economics 30 (4): 423-440. doi:10.1080/02692171.2015.1106445.

Lau, L. J. 1982. "On Identifying the Degree of Competitiveness from Industry Price and Output Data.” Economic Letters 10 (1-2): 93-99. doi:10.1016/0165-1765(82)90122-7.

Marquez, R. 2002. "Competition, Adverse Selection, and Information Dispersion in the Banking Industry.” The Review of Financial Studies 15 (3): 901-926. doi:10.1093/rfs/15.3.901.

McIntosh, C., and B. Wydick. 2005. "Competition and Microfinance." Journal of Development Economics 78 (2): 271-298. doi:10.1016/j.jdeveco.2004.11.008.

Mersland, R., and R. Ø. Strøm (2012). What Drives the Microfinance Lending Rate? Midwest Finance Association 2013 Annual Meeting Paper. 10.2139/ssrn.2144618 
Molyneux, P., J. Thornton, and D. M. Lloyd-Williams. 1996. "Competition and Market Contestability in Japanese Commercial Banking." Journal of Economics and Business 48 (1): 33-45. doi:10.1016/0148-6195(95)00047-X.

Navajas, S., J. Conning, and C. Gonzalez-Vega. 2003. "Lending Technologies, Competition and Consolidation in the Market for Microfinance in Bolivia." Journal of International Development 15 (6): 747-770. doi:10.1002/jid.1024.

Panzar, J. C., and J. N. Rosse. 1987. “Testing for "Monopoly” Equilibrium.” Journal of Industrial Economics 35 (4): 443-456. doi:10.2307/2098582.

Roodman, D. 2009. "How to Do Xtabond2: An Introduction to Difference and System GMM in Stata." The Stata Journal 9 (1): 86-136.

Shaffer, S. 1982. "A Non-Structural Test for Competition in Financial Markets.” In Proceedings of a Conference on Bank Structure and Competition, Federal Reserve Bank of Chicago, Chicago.

Turk-Ariss, R. 2009. "Competitive Behavior in Middle East and North Africa Banking Systems.” The Quarterly Review of Economics and Finance 49 (2): 693-710. doi:10.1016/j.qref.2008.03.002.

Vogelgesang, U. 2003. "Microfinance in Times of Crisis: The Effects of Competition, Rising Indebtedness, and Economic Crisis on Repayment Behavior." World Development 31 (12): 2085-2114. doi:10.1016/j.worlddev.2003.09.004.

Windmeijer, F. 2005. "A Finite Sample Correction for the Variance of Linear Efficient TwoStep GMM Estimators.” Journal of Econometrics 126 (1): 25-51. doi:10.1016/j.jeconom.2004.02.005. 
Table 1: Interpreting the Panzar-Rosse H-statistic

\begin{tabular}{|c|c|}
\hline Parameter region & Competitive environment test \\
\hline $\mathrm{H} \leq 0$ & $\begin{array}{l}\text {-Monopoly or conjectural variations short-term } \\
\text { oligopoly } \\
\text {-Each MFI operates independently as under monopoly } \\
\text { profit maximising conditions } \\
\text {-H is a decreasing function of the perceived demand } \\
\text { elasticity }\end{array}$ \\
\hline $0<\mathrm{H}<1$ & $\begin{array}{l}\text {-Monopolistic competition } \\
\text {-Free entry (Chamberlinian) equilibrium excess } \\
\text { capacity } \\
\text {-H is an increasing function of the perceived demand } \\
\text { elasticity }\end{array}$ \\
\hline $\mathrm{H}=1$ & $\begin{array}{l}\text {-Perfect competition, natural monopoly in a perfect } \\
\text { contestable market, or sales maximising firm subject to } \\
\text { break-even constraint } \\
\text {-Free entry equilibrium with full (efficient) capacity } \\
\text { utilisation }\end{array}$ \\
\hline Parameter region & Market equilibrium test \\
\hline $\mathrm{H}=0$ & Equilibrium \\
\hline $\mathrm{H} \leq 0$ & Disequilibrium \\
\hline
\end{tabular}

Source: Molyneux, Thornton and Lloyd-Williams (1996). 
Table 2: Description and definition of variables

\begin{tabular}{ll}
\hline Variable name & Description \\
\hline Interest income & Interests and revenues scaled by (assimilated over) total \\
& assets \\
& Source: Authors' calculations using the MFI-level yearly \\
& financial data from the MIX \\
& Ratio of net operating income (less taxes) to total assets \\
& Source: Authors' calculations using the MFI-level yearly \\
& financial data from the MIX \\
Return-on-assets & Ratio of personnel expenses to total assets. Personnel \\
& expenses include wages and salaries, social security \\
& contributions, contributions to pension funds, and other \\
Unit price of labour & staff-related expenses. \\
& Source: The yearly MIX data \\
& Ratio of interest expenses to total assets (current \\
& accounts, savings accounts, time deposits, repurchase \\
agreements, as well as alternative funding sources such & as retail bonds). \\
Source: The yearly MIX data \\
Ratio of administrative expenses to total assets. \\
Administrative expenses include rents, service charges, \\
security, information systems and communications, other \\
Onit price of physical capital \\
office and insurance expenses, professional charges, \\
publicity and advertising, and depreciation. \\
Source: The yearly MIX data \\
Natural logarithm of total assets \\
Source: Authors' calculations using the MFI-level yearly \\
financial data from the MIX \\
Ratio of equity (capital) to total assets \\
Source: The yearly MIX data \\
Ratio of (gross) loans to total assets \\
Source: Authors' calculations using the MFI-level yearly \\
financial data from the MIX \\
\end{tabular}


Table 3: Summary/Descriptive statistics for the sampled MFIs over the period 2004-2009

\begin{tabular}{|c|c|c|c|c|c|c|c|c|}
\hline & No. of MFIs & Observations & Statistic & Assets & Loans & Equity & ROA & Interest Income \\
\hline \multirow{4}{*}{ India } & 106 & 453 & Mean & 24.407 & 20.786 & 3.774 & 0.004 & 1.079 \\
\hline & & & S.D. & 78.972 & 74.814 & 14.839 & 0.107 & 4.935 \\
\hline & & & Minimum & 0.000 & 0.000 & -0.397 & -1.013 & -7.152 \\
\hline & & & Maximum & 897.871 & 960.794 & 213.038 & 0.563 & 58.188 \\
\hline \multirow[t]{4}{*}{ Indonesia } & 45 & 191 & Mean & 8.099 & 6.277 & 2.300 & 0.016 & 0.275 \\
\hline & & & S.D. & 52.272 & 40.622 & 17.041 & 0.105 & 2.114 \\
\hline & & & Minimum & 0.001 & 0.001 & 0.000 & -0.560 & -0.434 \\
\hline & & & Maximum & 529.796 & 397.100 & 169.631 & 0.145 & 27.073 \\
\hline \multirow[t]{4}{*}{ Ecuador } & 50 & 245 & Mean & 27.233 & 21.549 & 3.831 & 0.022 & 0.368 \\
\hline & & & S.D. & 63.692 & 49.841 & 7.063 & 0.044 & 0.743 \\
\hline & & & Minimum & 0.091 & 0.078 & 0.015 & -0.232 & -0.710 \\
\hline & & & Maximum & 341.106 & 253.682 & 41.217 & 0.161 & 4.962 \\
\hline \multirow[t]{4}{*}{ Philippines } & 79 & 379 & Mean & 8.965 & 5.962 & 1.696 & 0.019 & 0.285 \\
\hline & & & S.D. & 12.296 & 8.294 & 2.211 & 0.080 & 0.575 \\
\hline & & & Minimum & 0.075 & 0.024 & -0.227 & -0.583 & -1.076 \\
\hline & & & Maximum & 81.916 & 55.827 & 15.814 & 0.229 & 4.182 \\
\hline \multirow[t]{4}{*}{ Peru } & 62 & 314 & Mean & 67.193 & 54.194 & 10.466 & 0.033 & 2.577 \\
\hline & & & S.D. & 137.802 & 112.773 & 16.446 & 0.063 & 4.991 \\
\hline & & & Minimum & 0.246 & 0.165 & -0.011 & -0.337 & -5.448 \\
\hline & & & Maximum & 1278.721 & 1040.561 & 111.594 & 0.164 & 35.932 \\
\hline
\end{tabular}

Note: Excepting ROA, statistics figures are in million US\$. Author's calculations based on MIX data collected from www.themix.org. ROA

figures are in percentages. 
Table 4: Static Revenue tests: Panzar-Rosse H-statistics of sampled MFIs in selected countries (dependent variable: log of interest income)

\begin{tabular}{llllll}
\hline & India & Indonesia & Ecuador & Philippines & Peru \\
\hline Capital-assets ratio & -0.455 & -1.569 & -1.764 & -1.469 & 0.071 \\
& $(0.591)$ & $(1.496)$ & $(1.237)$ & $(0.848)$ & $(0.570)$ \\
Price of funds & 0.317 & -0.080 & -0.169 & -0.603 & -0.263 \\
& $(0.381)$ & $(0.275)$ & $(0.197)$ & $(0.321)$ & $(0.156)$ \\
Price of labour & 0.016 & -0.338 & 0.006 & 0.628 & -0.948 \\
& $(0.293)$ & $(0.223)$ & $(0.349)$ & $(0.508)$ & $(0.565)$ \\
Price of physical capital & 0.180 & $-0.586^{*}$ & -0.554 & -0.228 & $-1.106^{* * *}$ \\
& $(0.210)$ & $(0.243)$ & $(0.324)$ & $(0.409)$ & $(0.278)$ \\
Loans-assets ratio & 0.838 & 1.141 & 1.013 & 0.222 & $2.512^{*}$ \\
& $(0.708)$ & $(0.959)$ & $(1.051)$ & $(0.565)$ & $(1.141)$ \\
Size & $16.152^{* * *}$ & $22.911^{*}$ & 4.168 & $18.777^{* * *}$ & $12.166^{* * *}$ \\
& $(2.412)$ & $(8.899)$ & $(5.866)$ & $(3.496)$ & $(2.608)$ \\
PR H-statistics & 0.512 & -1.003 & -0.716 & $-2.316^{* * *}$ \\
P-value & $(0.200)$ & $(0.053)$ & $(0.229)$ & $(0.781)$ & $(0.000)$ \\
Monopoly H = 0 & 1.64 & 3.76 & 1.45 & 0.08 & $18.59^{* * *}$ \\
P-value & $(0.2003)$ & $(0.0526)$ & $(0.229)$ & $(0.781)$ & $(0.000)$ \\
Perfect Competition H $=1$ & 1.49 & $14.98^{* * *}$ & $8.31^{* *}$ & 2.71 & $38.11^{* * *}$ \\
P-value & $(0.2224)$ & $(0.000)$ & $(0.004)$ & $(0.0996)$ & $(0.000)$ \\
Hansen J-test (P-value) & 0.0975 & 0.4469 & 0.3316 & 0.1404 & 0.1682 \\
Observations (Groups) & $221(56)$ & $89(31)$ & $182(44)$ & $242(53)$ & $242(50)$ \\
\hline
\end{tabular}

Note: All variables are in logs. Fixed effects GMM estimates reported. Robust standard errors in the parentheses. Time effects were included, are not presented here. $* \mathrm{p}<0.05, * * \mathrm{p}<0.01, * * * \mathrm{p}<0.001$ 
Table 5: Static Revenue tests: Long-run E-statistics of sampled MFIs in selected countries (dependent variable: log of return-on-assets)

\begin{tabular}{llllll}
\hline & India & Indonesia & Ecuador & Philippines & Peru \\
\hline Capital-assets ratio & 0.011 & 0.113 & 0.033 & -0.068 & -0.017 \\
& $(0.011)$ & $(0.140)$ & $(0.021)$ & $(0.035)$ & $(0.028)$ \\
Price of funds & 0.018 & 0.005 & -0.006 & -0.019 & -0.014 \\
& $(0.016)$ & $(0.013)$ & $(0.009)$ & $(0.011)$ & $(0.008)$ \\
Price of labour & -0.015 & -0.014 & -0.006 & 0.003 & 0.000 \\
& $(0.013)$ & $(0.035)$ & $(0.017)$ & $(0.015)$ & $(0.019)$ \\
Price of physical capital & -0.008 & -0.017 & 0.005 & -0.019 & -0.016 \\
& $(0.007)$ & $(0.023)$ & $(0.014)$ & $(0.013)$ & $(0.016)$ \\
Loans-assets ratio & 0.016 & -0.042 & 0.041 & -0.019 & 0.043 \\
& $(0.015)$ & $(0.085)$ & $(0.041)$ & $(0.032)$ & $(0.032)$ \\
Size & -0.120 & -0.321 & 0.208 & 0.039 & -0.089 \\
& $(0.096)$ & $(0.720)$ & $(0.194)$ & $(0.120)$ & $(0.109)$ \\
Long-run E-statistics & -0.005 & -0.025 & -0.007 & -0.034 & -0.031 \\
P-value & $(0.748)$ & $(0.669)$ & $(0.780)$ & $(0.090)$ & $(0.298)$ \\
Long-run Equilibrium E $=0$ & 0.10 & 0.18 & 0.08 & 2.87 & 1.08 \\
P-value & $(0.748)$ & $(0.669)$ & $(0.780)$ & $(0.090)$ & $(0.298)$ \\
Hansen J-test (P-value) & 0.1184 & 0.8065 & 0.1373 & 0.9379 & 0.2734 \\
Observations (groups) & $194(51)$ & $102(34)$ & $212(45)$ & $268(55)$ & $226(48)$ \\
\hline Note: All varibles are & &
\end{tabular}

Note: All variables are in logs. Return-on-assets (ROA) is transformed as 1+ROA. Fixed effects GMM estimates reported. Robust standard errors in the parentheses. Time effects were included, but not presented here. $* \mathrm{p}<0.05, * * \mathrm{p}<0.01, * * * \mathrm{p}<0.001$ 
Table 6: Dynamic Revenue test: Panzar-Rosse H-statistics of sampled MFIs in selected countries based on dynamic revenue tests (dependent variable- $-\log$ of interest income)

\begin{tabular}{|c|c|c|c|c|c|}
\hline & India & Indonesia & Philippines & Peru & Ecuador \\
\hline \multirow[t]{2}{*}{ Capital-assets ratio } & $1.386 * *$ & 0.281 & $2.391 * * *$ & 3.539 & 1.629 \\
\hline & $(0.499)$ & $(2.543)$ & $(0.544)$ & $(3.008)$ & $(1.457)$ \\
\hline \multirow{2}{*}{ Lagged capital-assets ratio } & $-1.005 * *$ & 0.572 & $-1.646^{* *}$ & -2.969 & -1.947 \\
\hline & $(0.326)$ & $(2.032)$ & $(0.504)$ & $(2.152)$ & $(1.617)$ \\
\hline \multirow[t]{2}{*}{ Price of funds } & -0.129 & $-1.020^{*}$ & -0.107 & -0.255 & -0.518 \\
\hline & $(0.364)$ & $(0.500)$ & $(0.157)$ & $(0.380)$ & $(0.446)$ \\
\hline \multirow[t]{2}{*}{ Lagged price of funds } & 0.081 & 0.143 & 0.142 & 0.060 & -0.244 \\
\hline & $(0.442)$ & $(0.513)$ & $(0.197)$ & $(0.454)$ & $(0.318)$ \\
\hline \multirow[t]{2}{*}{ Price of labour } & $-0.587 * *$ & 0.046 & -0.090 & -0.583 & -0.598 \\
\hline & $(0.196)$ & $(0.375)$ & $(0.309)$ & $(0.486)$ & $(0.531)$ \\
\hline \multirow[t]{2}{*}{ Lagged price of labour } & $0.430 *$ & $-0.650^{*}$ & 0.094 & 0.863 & 1.217 \\
\hline & $(0.214)$ & $(0.276)$ & $(0.360)$ & $(0.772)$ & $(0.685)$ \\
\hline \multirow{2}{*}{ Price of physical capital } & -0.004 & -0.186 & -0.436 & -0.306 & -0.479 \\
\hline & $(0.125)$ & $(0.171)$ & $(0.289)$ & $(0.534)$ & $(0.945)$ \\
\hline \multirow[t]{2}{*}{ Lagged price of physical capital } & 0.026 & -0.157 & 0.201 & -0.119 & 0.367 \\
\hline & $(0.154)$ & $(0.150)$ & $(0.288)$ & $(0.924)$ & $(0.714)$ \\
\hline \multirow[t]{2}{*}{ Loans-assets ratio } & $1.372 *$ & 1.176 & 0.367 & 1.053 & -0.183 \\
\hline & $(0.590)$ & $(1.029)$ & $(0.351)$ & $(1.072)$ & $(1.078)$ \\
\hline \multirow[t]{2}{*}{ Lagged loans-assets ratio } & -0.733 & 1.068 & 0.012 & -0.670 & 0.930 \\
\hline & $(0.472)$ & $(0.927)$ & $(0.480)$ & $(1.486)$ & $(1.021)$ \\
\hline \multirow[t]{2}{*}{ Size } & $32.094 * * *$ & 30.947 & $59.433 * * *$ & 54.027 & $49.405^{*}$ \\
\hline & $(3.837)$ & $(26.674)$ & $(9.669)$ & $(33.745)$ & $(18.942)$ \\
\hline \multirow[t]{2}{*}{ Lagged size } & $-23.286^{* * *}$ & -7.762 & $-47.287 * * *$ & -36.369 & $-35.752 *$ \\
\hline & $(4.131)$ & $(20.309)$ & $(9.391)$ & $(39.078)$ & $(15.249)$ \\
\hline \multirow[t]{2}{*}{ Lagged interest income } & $0.500 * *$ & -0.344 & $0.242 *$ & 0.040 & 0.213 \\
\hline & $(0.161)$ & $(0.291)$ & $(0.103)$ & $(0.647)$ & $(0.413)$ \\
\hline \multirow{2}{*}{ Constant } & $-18.504 * *$ & -50.107 & $-23.930 * * *$ & $-37.691 *$ & -30.189 \\
\hline & $(5.683)$ & $(45.461)$ & $(3.851)$ & (16.147) & (15.368) \\
\hline
\end{tabular}


Table 6: Panzar-Rosse H-statistics of sampled MFIs in selected countries based on dynamic revenue tests (dependent variable - log of interest income) (contd.)

\begin{tabular}{|c|c|c|c|c|c|}
\hline PR H-statistic & $\begin{array}{l}-0.721 * \\
(0.292)\end{array}$ & $\begin{array}{l}-1.159 \\
(0.888)\end{array}$ & $\begin{array}{l}-0.632 \\
(0.503)\end{array}$ & $\begin{array}{l}-1.144 * \\
(0.494)\end{array}$ & $\begin{array}{l}-1.596 \\
(1.204)\end{array}$ \\
\hline Monopoly $\mathrm{H}=0$ & $6.11 *$ & 1.71 & 1.58 & $5.36^{*}$ & 1.76 \\
\hline P-value & 0.0161 & 0.1993 & 0.2144 & 0.0245 & 0.1916 \\
\hline Perfect Comp. $\mathrm{H}=1$ & $34.82 * * *$ & $5.92 *$ & $10.51 * *$ & $18.84 * * *$ & $4.65 *$ \\
\hline P-value & 0.000 & 0.0197 & 0.002 & 0.0001 & 0.0364 \\
\hline F-test & 48.22 & 2227.45 & 41.90 & 101.95 & 57.12 \\
\hline P-value & 0.000 & 0.000 & 0.000 & 0.000 & 0.000 \\
\hline Sargan & 35.49 & 8.08 & 43.05 & 15.48 & 14.33 \\
\hline P-value & 0.046 & 0.232 & 0.007 & 0.079 & 0.111 \\
\hline Hansen J-test (p-value) & 0.701 & 0.811 & 0.508 & 0.519 & 0.151 \\
\hline AR (1) & 0.025 & 0.232 & 0.008 & 0.570 & 0.275 \\
\hline AR (2) & 0.197 & 0.911 & 0.189 & 0.942 & 0.093 \\
\hline Number of instruments & 43 & 25 & 43 & 29 & 29 \\
\hline Lags used & $2 \_2$ & $2 \_2$ & $2 \_2$ & $2 \_2^{\#}$ & $4 \_4^{\S}$ \\
\hline Obs. (Groups) & $203(66)$ & $85(40)$ & $208(60)$ & $221(54)$ & $148(46)$ \\
\hline
\end{tabular}

Note: All variables are in logs. Time effects included, but not presented here. \#Instruments used in GMM style equation (difference) only. $\S$ Instruments used in GMM style equation (level) only. $* \mathrm{p}<0.05, * * \mathrm{p}<0.01, * * * \mathrm{p}<0.001$ 
Table 7: Dynamic Revenue tests: Long-run E-statistics of sampled MFIs in selected countries (dependent variable: log of return-on-assets)

\begin{tabular}{|c|c|c|c|c|c|}
\hline & India & Indonesia & Philippines & Peru & Ecuador \\
\hline Capital-assets ratio & $\begin{array}{l}0.016 \\
(0.011)\end{array}$ & $\begin{array}{l}0.008 \\
(0.039)\end{array}$ & $\begin{array}{l}0.122 * \\
(0.055)\end{array}$ & $\begin{array}{l}0.040 \\
(0.068)\end{array}$ & $\begin{array}{l}0.049 \\
(0.052)\end{array}$ \\
\hline Lagged capital-assets ratio & $\begin{array}{l}-0.013 \\
(0.010)\end{array}$ & $\begin{array}{l}-0.011 \\
(0.036)\end{array}$ & $\begin{array}{l}-0.119 * \\
(0.053)\end{array}$ & $\begin{array}{l}-0.044 \\
(0.040)\end{array}$ & $\begin{array}{l}0.008 \\
(0.034)\end{array}$ \\
\hline Price of funds & $\begin{array}{l}-0.002 \\
(0.013)\end{array}$ & $\begin{array}{l}0.028 \\
(0.015)\end{array}$ & $\begin{array}{l}-0.005 \\
(0.010)\end{array}$ & $\begin{array}{l}-0.011 \\
(0.020)\end{array}$ & $\begin{array}{l}0.017 \\
(0.009)\end{array}$ \\
\hline Lagged price of funds & $\begin{array}{l}-0.001 \\
(0.012)\end{array}$ & $\begin{array}{l}-0.006 \\
(0.007)\end{array}$ & $\begin{array}{l}0.006 \\
(0.007)\end{array}$ & $\begin{array}{l}-0.003 \\
(0.014)\end{array}$ & $\begin{array}{l}-0.010 \\
(0.009)\end{array}$ \\
\hline Price of labour & $\begin{array}{l}-0.017^{*} \\
(0.006)\end{array}$ & $\begin{array}{l}-0.020 \\
(0.019)\end{array}$ & $\begin{array}{l}-0.028 \\
(0.019)\end{array}$ & $\begin{array}{l}-0.028 \\
(0.034)\end{array}$ & $\begin{array}{l}-0.033 \\
(0.031)\end{array}$ \\
\hline Lagged price of labour & $\begin{array}{l}0.014^{*} \\
(0.007)\end{array}$ & $\begin{array}{l}0.016 \\
(0.016)\end{array}$ & $\begin{array}{l}0.029 \\
(0.019)\end{array}$ & $\begin{array}{l}0.034 \\
(0.028)\end{array}$ & $\begin{array}{l}0.017 \\
(0.022)\end{array}$ \\
\hline Price of physical capital & $\begin{array}{l}-0.001 \\
(0.006)\end{array}$ & $\begin{array}{l}-0.031 * * * \\
(0.007)\end{array}$ & $\begin{array}{l}-0.036^{*} \\
(0.017)\end{array}$ & $\begin{array}{l}-0.021 \\
(0.019)\end{array}$ & $\begin{array}{l}0.002 \\
(0.018)\end{array}$ \\
\hline Lagged price of physical capital & $\begin{array}{l}0.001 \\
(0.005)\end{array}$ & $\begin{array}{l}0.015 \\
(0.011)\end{array}$ & $\begin{array}{l}0.030^{*} \\
(0.014)\end{array}$ & $\begin{array}{l}0.000 \\
(0.010)\end{array}$ & $\begin{array}{l}-0.002 \\
(0.018)\end{array}$ \\
\hline Loans-assets ratio & $\begin{array}{l}0.023 \\
(0.012)\end{array}$ & $\begin{array}{l}-0.026 \\
(0.061)\end{array}$ & $\begin{array}{l}0.012 \\
(0.026)\end{array}$ & $\begin{array}{l}0.064 \\
(0.040)\end{array}$ & $\begin{array}{l}0.002 \\
(0.036)\end{array}$ \\
\hline Lagged loans-assets ratio & $\begin{array}{l}0.013 \\
(0.016)\end{array}$ & $\begin{array}{l}-0.010 \\
(0.030)\end{array}$ & $\begin{array}{l}-0.022 \\
(0.027)\end{array}$ & $\begin{array}{l}0.006 \\
(0.037)\end{array}$ & $\begin{array}{l}-0.001 \\
(0.042)\end{array}$ \\
\hline Size & $\begin{array}{l}0.359 \\
(0.231)\end{array}$ & $\begin{array}{l}0.339 \\
(0.408)\end{array}$ & $\begin{array}{l}1.413 * * \\
(0.460)\end{array}$ & $\begin{array}{l}0.884 * \\
(0.397)\end{array}$ & $\begin{array}{l}0.951 \\
(0.561)\end{array}$ \\
\hline Lagged size & $\begin{array}{l}-0.321 \\
(0.193)\end{array}$ & $\begin{array}{l}-0.366 \\
(0.426)\end{array}$ & $\begin{array}{l}-1.424 * * \\
(0.440)\end{array}$ & $\begin{array}{l}-0.922 * \\
(0.371)\end{array}$ & $\begin{array}{l}-0.812 \\
(0.510)\end{array}$ \\
\hline Lagged return-on-assets & $\begin{array}{l}0.421 * * \\
(0.155)\end{array}$ & $\begin{array}{l}0.483^{* * *} \\
(0.112)\end{array}$ & $\begin{array}{l}0.725^{*} \\
(0.304)\end{array}$ & $\begin{array}{l}0.454 \\
(0.553)\end{array}$ & $\begin{array}{l}0.346^{* *} \\
(0.127)\end{array}$ \\
\hline Constant & $\begin{array}{l}-0.106 \\
(0.187)\end{array}$ & $\begin{array}{l}0.070 \\
(0.113)\end{array}$ & $\begin{array}{l}0.014 \\
(0.187)\end{array}$ & $\begin{array}{l}0.034 \\
(0.106)\end{array}$ & $\begin{array}{l}-0.323 \\
(0.172)\end{array}$ \\
\hline
\end{tabular}


Table 7: Long-run E-statistics of sampled MFIs in selected countries based on dynamic revenue tests (dependent variable: log of return-onassets) (contd.)

\begin{tabular}{|c|c|c|c|c|c|}
\hline LR E-statistic & $\begin{array}{l}-0.020 \\
(0.012)\end{array}$ & $\begin{array}{l}-0.023 \\
(0.022)\end{array}$ & $\begin{array}{l}-0.068 \\
(0.038)\end{array}$ & $\begin{array}{l}-0.060 \\
(0.032)\end{array}$ & $\begin{array}{l}-0.015 \\
(0.036)\end{array}$ \\
\hline LR Equilibrium $\mathrm{E}=0$ & 2.96 & 1.11 & 3.31 & 3.61 & 0.17 \\
\hline P-value & 0.0892 & 0.2988 & 0.0736 & 0.0624 & 0.6795 \\
\hline F-test & 5.67 & 117.14 & 8.54 & 72.23 & 9.65 \\
\hline P-value & 0.000 & 0.000 & 0.000 & 0.000 & 0.000 \\
\hline Sargan & 34.98 & 53.77 & 48.83 & 13.46 & 26.72 \\
\hline $\mathrm{P}$-value & 0.052 & 0.000 & 0.001 & 0.265 & 0.268 \\
\hline Hansen J-test (p-value) & 0.463 & 0.244 & 0.393 & 0.305 & 0.615 \\
\hline $\mathrm{AR}(1)$ & 0.061 & 0.208 & 0.003 & 0.265 & 0.193 \\
\hline $\operatorname{AR}(2)$ & 0.789 & 0.862 & 0.833 & 0.933 & 0.154 \\
\hline Number of instruments & 43 & 41 & 43 & 31 & 43 \\
\hline Lags used ${ }^{\#}$ & $2 \_2$ & $2 \_3$ & $2 \_2$ & $2 \_2$ & 4_4 \\
\hline Obs. (Groups) & $2 \overline{5} 4(82)$ & $9 \overline{7}(43)$ & $2 \overline{4} 2(64)$ & $2 \overline{6} 2(60)$ & $192(49)$ \\
\hline
\end{tabular}

Note: All variables are in logs. Return-on-assets (ROA) is transformed as $1+\mathrm{ROA}$. Time effects were included, but not presented here. $* \mathrm{p}<0.05$, $* * \mathrm{p}<0.01, * * * \mathrm{p}<0.001$ 